\title{
Spatial distribution and controlling factors of snow avalanche and debris flow in Parâng Mountains
}

\author{
Ionela Georgiana Gavrilă, Olimpiu Pop, Csaba Horvath, Flaviu Meseșan, Iulian Holobâcă \\ Faculty of Geography \\ Babeș-Bolyai University \\ Cluj-Napoca, Romania
}

\begin{abstract}
The alpine slopes of Parâng Mts. are prone to snow avalanche (SA) and debris flow (DF) activity due to favorable lithological, topo-climatic and vegetation cover conditions. Since tourism activities are continuously increasing, tourists and related infrastructure in this area might be exposed to different levels of risk. Our study is a preliminary research that aims to analyze the spatial distribution and controlling factors of SA and DF processes in Parâng Mts., which represent natural hazards threating the areas destined for tourism activities and associated infrastructure. First, the spatial distribution pattern of SA paths and DF tracks was identified and mapped on orthophotoplans, then checked in the field and integrated in a database for analysis. Subsequently, a set of instability factors influencing directly the spatial distribution of SA and DF activity were analyzed. The following instability factors were taken into consideration and statistically analyzed using ArcGIS software: slope, altitude, aspect, planar and profile curvature (automatically extracted from $10 \mathrm{~m}$ resolution DEM), vegetation cover (mapped on orthophotoplans) and lithology (extracted from the geological maps at 1:200.000 scale). Information regarding the spatial distribution of tourist frequented areas and the related infrastructure (hiking trails, chalets, ski lifts, ski pistes etc.) were analyzed in conjunction with the spatial distribution of geomorphic process activity. In areas with tourism activities, future research will focus on mapping terrain susceptibility to SA and DF processes. Moreover, dendrogeomorphic reconstructions will allow to determine the occurrence probability of SA and DF activity, which will serve to finally get an accurate geomorphic hazard zonation within the study area.
\end{abstract}

Keywords - spatial distribution; controlling factors; snow avalanche; debris flow; Parâng Mountains; ZonaGeoTour

\section{INTRODUCTION}

In the present-day period, an increase of snow avalanche (SA) and debris-flow (DF) activity was reported in various massifs belonging to Carpathian range, causing material damages and fatalities in inhabited areas [1], [2], [3], [4], [5]. So far, in Parâng Mts., only SA activity was investigated and reported in few case studies by [1] and [6], even if both geomorphic processes are widespread on the alpine and subalpine steep slopes of the massif being natural hazards threating the touristic areas and related infrastructure.

Within the present context of tourism planning policies regarding the extension of tourism infrastructure in investigated area, a better understanding of behavior of SA and DF geomorphic processes is crucial for the mitigation of hazards and associated risks.

Our study is the first stage of the geomorphic hazard assessment in areas frequented by tourists from Parâng Mts. It aims to analyze the spatial distribution and instability factors which control the SAs and DFs. This research also aims at identifying those touristic areas and associated infrastructure exposed to geomorphic hazards.

\section{STUDY AREA}

Parâng Mts. belongs to Southern Carpathians, reaching the maximum altitude in Parângul Mare Peak (2519 m a.s.l.). For our study we took into consideration the high areas of Parâng Mts. where peaks, narrow crests and steep slopes are common, being prone to geomorphic activity. The total surface of study area is $195.5 \mathrm{~km}^{2}$. In terms of lithology, magmatic rocks (granites and granodiorites) are widespread in the highest part of the mountains, while metamorphic and sedimentary rocks (amphibolite, crystalline schists, limestone) are common at its periphery [7]. Overall morphology is represented by narrow ridges, glacial cirques and valleys etc., being the result of Pleistocene and Holocene glacial and periglacial activity. The pre-existing glacial and periglacial landforms are reshaped in the present-day by SA and DF geomorphic activity [7] and [1]. Above $1800 \mathrm{~m}$ a.s.l., the average annual temperature is below $2^{\circ} \mathrm{C}$ and the precipitation amount is $1200 \mathrm{~mm} /$ year, leading to the development of alpine shrubs and alpine meadow. Between 1400-1700 m the average annual temperature is around $2-3^{\circ} \mathrm{C}$ and precipitation amount is about 1000-1200 mm/year. Coniferous belt extent roughly at mentioned altitudes, being dominated by Norway spruce (Picea abies (L.) Karst.) forests [6]. 


\section{METHODS}

In order to achieve the proposed goal of our study, first, the spatial distribution pattern of SA paths and DF tracks was identified and mapped as polygons on orthophotos. The preliminary inventory map was then partially checked and corrected in the field. In this stage, field observations were also made in the areas with high density of SA path and DF tracks to obtain information regarding instability factors involved in the process initiation.

The following controlling factors were subsequently took into consideration for analysis: slope, altitude, aspect, planar and profile curvature, vegetation land cover and lithology. Slope, altitude, aspect, planar and profile curvature were automatically derived from $10 \mathrm{~m}$ resolution DEM; while lithology was extracted from the existing geological maps at 1:200.000 scale. Vegetation cover was identified and mapped on orthophotos in 6 different classes: forest vegetation; forest and subalpine shrubs; subalpine shrubs; shrubs and alpine meadows; subalpine meadow; bare rock; and secondary pasture. In this stage, the tourism infrastructure (hiking trails, chalets, ski lifts, ski pistes etc.) was also mapped using the orthophotos.

Statistical analyses were completed in order to assess the role of each instability factor on the spatial distribution of SA and DF using two different methods.

In case of SA, within mapped polygons, only the areas with slopes above 250 were considered as starting zones. Through spatial analysis, the area of every class of the instability factors was measured and by using ArcGIS 10, Spatial Analyst Tools toolbox "Zonal/Tabulate Area" extension, the affected part of them was computed.

In case of DF the exact initialization of process was identified and represented as point. ArcGIS 10 software was used to count the number of points of DF source areas within each class using spatial analysis. The instability factors took into consideration in this case were the same, without lithology.

Subsequently, in order to identify the vulnerable areas to geomorphic hazard, information regarding the spatial distribution of areas frequented by tourists and the related infrastructure were analyzed in conjunction with the spatial distribution of SA and DF activity.

\section{RESUlts}

In total, 43 SA starting areas and 1459 DF source zones were identified in Parâng Mts. The statistical results shows that SA starting areas are mainly located above $2000 \mathrm{~m}$, on steep slopes over $25^{\circ}$, in cirque walls or glacial valleys. The most SA starting areas are located on slopes southwest, south and south-east oriented due to the favorable topo-climatic conditions (high insolation, increased air temperature) (tab. 1). Regarding the vegetation cover, the most SA starting areas is on steep slopes situated above treeline, covered with alpine shrubs, alpine meadows and bare rock.

The highest density of DF source zones is between $1600-1800 \mathrm{~m}(42.36 \%)$, on steep slopes ranging between $20^{\circ}$ to $40^{\circ}$ (1.090 DF source zones, representing $74,7 \%$ from the total number) (tab. 2). DF source zones mainly correspond with the steep slopes of bare rock (42.5\%), represented by granites and granitoides (46.9\% from the total number of inventoried DF source zones) or poorly consolidated debris slopes. The cliff faces also helps to concentrate the runoff into talus surfaces, being an important controlling factor of DF.

Data resulted from analysis between spatial distribution of geomorphic processes and tourism infrastructures revealed that from a total length of $174 \mathrm{~km}$ of hiking trails, $14 \mathrm{~km}$ are exposed to SAs.

TABLE I. ASPECT OF DEBRIS FlOW STARTING ZONES IN PARÂNG MTS

\begin{tabular}{|l|l|c|c|}
\hline No. & Aspect & $\begin{array}{c}\text { Surface of } \\
\text { starting zone } \\
\left(\mathbf{k m}^{\mathbf{2}} \mathbf{)}\right.\end{array}$ & $\begin{array}{c}\text { Percentage } \\
\mathbf{( \% )}\end{array}$ \\
\hline 1 & Flat & 0 & 0 \\
\hline 2 & N & 1.04 & 10.4 \\
\hline 3 & NE & 1.59 & 11.1 \\
\hline 4 & E & 2.24 & 12.1 \\
\hline 5 & SE & 2.33 & 11.2 \\
\hline 6 & S & 2.75 & 12.1 \\
\hline 7 & SW & 3.82 & 13.5 \\
\hline 8 & W & 2.94 & 15.7 \\
\hline 9 & NW & 1.17 & 13.9 \\
\hline & Total & 17,88 & 100 \\
\hline
\end{tabular}

TABLE II.

SLOPE ANGLES OF DEBRIS FLOW SOURCE ZONES IN PARÂNG MTS.

\begin{tabular}{|l|l|c|c|}
\hline No. & \multicolumn{1}{|c|}{ Slope angles $\left.\mathbf{(}^{\circ}\right)$} & $\begin{array}{c}\text { Number of DF } \\
\text { tracks }\end{array}$ & $\begin{array}{c}\text { Percentage } \\
(\mathbf{\%})\end{array}$ \\
\hline 1 & $<20$ & 166 & 11.4 \\
\hline 2 & $20-30$ & 565 & 38.7 \\
\hline 3 & $30-40$ & 525 & 36.0 \\
\hline 4 & $>40$ & 203 & 13.9 \\
\hline & Total & 1459 & 100 \\
\hline
\end{tabular}

\section{CONCLUSIONS AND PERSPECTIVES}

The spatial and statistical analyses reveal that morphometric parameters, vegetation cover and lithology highly control the spatial distribution of SA and DF in Parâng Mts. Touristic infrastructure and related activities are exposed to geomorphic hazards, therefore the monitoring of processes and hazard assessment is compulsory for tourist safety. In the areas with tourist activities, future research will focus on mapping terrain susceptibility to SA and DF processes. Moreover, the occurrence probability of both geomorphic activity will further be assess using dendrogeomorphological methods. This data will serve to obtain an accurate geomorphic hazard zonation in the Parâng Mts.

\section{ACKNOWLEDGMENT}

This work has been supported from the Bilateral Project ZONAGEOTOUR " Zonage des aléas géomorphologiques dans les espaces touristiques des massifs du Parâng (Roumanie) et du Pirin (Bulgarie) » (Geomorphic hazard zonation in tourism areas of Parâng Mts., Romania and Pirin Mts., Bulgaria), financed by the 
Agence Universitaire de la Francophonie (AUF) and Fonds de Recherche Scientifique (FRS) de Bulgarie.

\section{REFERENCES}

[1] O. T. Pop, I. G. Gavrilă, G. Rosian, F. Mesesan, A. Decaulne, I. H. Holobâcă and T. Anghel, "A century-long snow avalanche chronology reconstructed from tree-rings in Parâng Mountains (Southern Carpathians, Romania)", Quaternary International, vol. 415, pp. 230- 240, 2016.

[2] M. Voiculescu, "Snow-avalanche hazards in the Făgăraş Massif (Southern Carpathians): Romanian Carpathians-Management and perspectives", Natural Hazards, vol. 51, pp. 459-475, 2009.
[3] J. Hreško, G. Bugár, M. Boltižiar, and F. Kohút, "The dynamics of recent geomorphic processes in the Alpine zone of the Tatra Mountains", Geographia Polonica, vol. 81, no. 1, pp. 53-65, 2008.

[4] A. Kotarba, "Geomorphic activity of debris flows in the Tatra Mts and in other European Mountains", Geographia Polonica, vol. 80, no. 2, pp. 137-150, 2007.

[5] Z. Rączkowska, "Recent geomorphic hazards in the Tatra Mountains", Studia Geomorphologica Carpatho-Balcanica, vol. 40, pp. 45-60, 2006.

[6] F. Meseșan, O. Pop, I.G. Gavrilă and D. Petrea, "Snow avalanche activity in Parâng ski area revealed by tree-rings", Studia Geographia, vol. LIX, no. 2, pp. 47-56, 2014.

[7] R. Popescu, A. Vespremeanu-Stroe, A. Onaca, and N. Cruceru, "Permafrost research in the granitic massifs of Southern Carpathians (Parâng Mountains)", Zeitschrift für Geomorphologie, vol. 59, no. 1, pp. 1-20, 2015 